\title{
Beyond the Gaze. Future of theories of perception and representation with regard to Laura Mulvey's psychoanalysis of looking in the article Visual Pleasure and Narrative Cinema.
}

\author{
Iwona Kościelecka \\ University of Gdansk/ Institute of Culture Research
}

\begin{abstract}
The aim of this presentation is to introduce and discuss the key concepts included in the article written by Laura Mulvey Visual Pleasure and Narrative Cinema which was published in SCREEN in 1975 and initiated a discussion lasting until today in various fields researching the visual perception and representation. As Mulvey claims in the opening: the essay takes as its starting point the way film reflects, reveals and even plays on the straight, socially established interpretation of sexual difference which controls images, erotic ways of looking and spectacle. Concepts used in psychoanalysis by Sigmund Freud and later by Jacques Lacan such as: scopophilia as active, erotic instinct being the basis for pleasure in looking, voyeuristic desire to see, threat of castration and sadism connected with voyeurism, sexual difference and sexual imbalance, fetishisctic scopophilia, or a woman as a 'lack', were all used by Mulvey as a political weapon in destruction of categories influencing visual pleasure and social formations of a woman as a silent/passive image in films. The polemic around article's issues regarding the male gaze and its phallocentric order in films, with a usage of psychoanalytic tools, influenced theories of visual perception and representation in art, sociology, anthropology, aesthetics, and all contemporary analyses of visual culture. The presentation will follow selected works of women theorists who discussed and evolved the concepts of the gendered gaze developing polemic in articles and books such as: Film and the Masquerade by Mary Ann Doane theorising the female spectator and censorship of the female gaze, Uses of the Erotic by Audre Lorde, the Persistence of Vision by Donna Haraway Feminist Pleasures and Fetishising the Gaze by Amelia Jones, as well as the Matrixial Gaze by Bracha Ettinger.
\end{abstract}

Keywords: fetish; male gaze; matrixial gaze; scopophilia as erotic instinct; sexual difference; woman as image; visual culture. 